\title{
The Pragmatics of Nigerian English in Chimamanda Ngozi Adichie's Novels
}

\author{
Romanus Aboh \\ University of Uyo \\ Correspondence concerning this article should be addressed to Romanus Aboh, University of Uyo, \\ Nwaniba Road, Uyo, Akwa Ibom State, Nigeria, 1017. E-mail: romeaboh@gmail.com

\section{Happiness Uduk \\ University of Uyo} \\ Correspondence concerning this article should be addressed to Happiness Uduk, University of Uyo, \\ Nwaniba Road, Uyo, Akwa Ibom State, Nigeria, 1017. E-mail: usienemfon@yahoo.com
}

\begin{abstract}
There are relatively few studies that have examined the pragmatization of Nigerian English in Adichie's novelistic oeuvre. This study seeks to fill that gap by undertaking a pragmatic analysis of Nigerian English in Adichie's Purple Hibiscus, Half of a Yellow Sun and Americanah in order to account for the pragmatic relation between utterances and meaning explication. The theory adopted for this study is pragmatic context. The analysis indicates that the use of English as reflected in the novels is pragmatically oriented which, by and large, helps elucidate the particular use of English in the non-literary situation in Nigeria. Also, the analysis demonstrates that the contexts, in which these Nigerian English expressions occur, significantly, draw from Nigeria's sociocultural milieu, and the sociocultural milieu shapes the meaning or sense discourse participants squeeze out of utterances in interactive situations.
\end{abstract}

Keywords: Nigerian English, Igbosim, Code-switching, pragmatics, Adichie

An earlier study (Aboh \& Uduk, 2015), notes that it is perhaps unthinkable to discuss the issue of language in Nigerian literature without specifying the underlying pragmatism that informs a writer's use of language. It is understandable that languages differ in their "socio-functional use and languages serve the purpose of communication but the forms of the conditions of their use are connected with a definite socio-historical situation" (Akujobi, 2014, p. 107). Akujobi's postulate is most probably informed by the colonization of Africa. The colonization of Africa both helped to make and mar Africa, depending on the perspective from which one sees colonialism. In terms of language, colonial education, arguably, made it possible for the African writer to "carry" his/her imaginative initiative beyond the shores of Africa. But the African writer does not write entirely in the "colonial" language. As observed in Nigerian prose fiction, the Nigerian writer writes in a language called "Nigerian literary English". This phrase describes the many modification processes the English language has undergone since it came in contact with indigenous languages. Nigerian novelists', just as have other African novelists' use of language, demonstrates that literature provides a fertile ground for the modifications of English.

It is our recognition of some peculiarities in the English used in Nigerian literature that motivates this study. This study focuses on a variety of the English language used in the three novels - Purple Hibiscus (2004, henceforth Purple), Half of a Yellow Sun (2006, hereafter Half) and Americanah (2013) written by the celebrated Nigerian female novelist, Chimamanda Ngozi Adichie. Adichie's novels, as well as her collections of short stories, have enjoyed critical scholarly attention - Ogwude (2011), Olusola and Alabib (2013). Anyokwu (2011), for example, draws his readers' attention to Adichie's largely adroit interweave of thoroughly domesticated English complete with Nigerianisms, slang, buzz-words, among others. He goes on to state that Adichie is exceptional 
and commends her ability to mix the exoglossic and the endoglossic codes, that is, English and Igbo in her narrative enterprise. In a relatively recent article, Yeibo and Akerele (2014), while examining the phonology of Adichie's Purple insightfully argue that as constitutive layers of language, phonic elements function as veritable parts of textual organization and are as useful and fundamental as other levels of language study. Despite the extensive critical attention Adichie's works have received, studies on her use of language from a pragmatic perspective are still lacking.

One popular way of analyzing language is to focus attention on the "purely" linguistic issues, more phonological and syntactic than lexical. But what constitutes the inner structure of language is its pragmatism - the way discourse participants deploy language to achieve their communicative intentions. People's ways of using language thus become a synchronization of their ideas and their intended message, and this link between language and function brings to one's mind the core value of literature. Our aim in this study is to examine the pragmatics of Nigerian English as reflected in the sampled texts. It is hoped that such a scholarly engagement will account not only for the aesthetics of Nigerian English, but also for the pragmatic acts that are instantiated when Adichie's characters use language in her novels.

\section{Materials and Methods}

\section{Theoretical Postulation: Pragmatic Context}

Pragmatics deals with meaning in contexts. It studies how human communication is effected through the intended meaning of the speaker and is decoded by the hearer taking into account the context. For Mey, pragmatics is "the study of the use of language in human communication as determined by the conditions of the society" $(2001$, p. 6). It can be inferred from Mey's definition that the core of pragmatic study is to analyze meaning from its context of use. Put differently, pragmatics studies the meaning of utterances as used in interactive situations, taking into consideration the context. Odebunmi (2015) provides an elaborate definition of pragmatics. He writes:

Pragmatics is the study of meaning that is constrained by discourse participants' context-determined or context-shaped roles, access to shared or accommodated beliefs, negotiation of discursive choices and interactive orientation. $(2015,199)$

This all-encompassing definition takes into account issues that concern the linguist who relies on pragmatics in his/her interaction with meaning. It considers the discourse participants and what informs their discursive context, which evidently shapes their use of language, what they undermine or consider an integral aspect of their communicative transaction, participants' mutually constructed meanings of words, and their "preferred or dispreferred interpretation of utterances" (2015, p. 199). It can be said that for pragmatics, context is the whole of meaning.

Context is the driving force of meaning. Conceptualized as "the spine of meaning" by Odebunmi (2006, p. 25), context plays an indispensible role in the full explication of what a speaker implies and what a hearer infers. It is expedient to stress that context in pragmatics differs considerably from context in several other disciplines. In most languagebased analyses, setting serves as the major frame of context. In pragmatics, however, "context refers to the dynamic, talk-connected condition that evokes co-experiential and current activity frames for the determination of senses of utterances" (Odebunmi, 2015, p. 200). Context, then, is not something fixed, but occurs in interactions in so far the meanings of utterances are interpreted based on the experiences discourse participants had prior to the current interaction.

In some instances, certain utterances or expressions suggest context. Even the culture of a people can suggest context. For example, in the BetteBendi cultural semantics of gossip if someone says "I have nothing to say", it does not mean s/he has put an end to the talk; rather, s/he has initiated some gossip. Predictably, the meaning or sense which the discourse participants make out of the interaction is determined by the context of the gossip. This pragmatic orientation of context appears to work contrary to the traditional concept of context where context relies on setting: church, school, home, etc. Pragmatic context, as already pointed out, goes far beyond the setting of an utterance since an utterance or an expression has the capacity to trigger its context. When such a contextualization takes place, what is said, how it is said and how what is said is understood or interpreted is not based on the setting, but on the context of the utterance. Context, therefore, embodies linguistic and non-linguistic factors of language use. It follows that when a word occurs or is used in isolation, one needs to place it in a situational, linguistic or cultural context because no word can really be understood out of context.

The use of the English language in the Nigerian context is different from its usage in Britain or America because in each context, the language is used to express the totality of the cultures of its users. The pragmatic features of Nigerian English (NE) are 
the aspects of NE that reflect the cultures, traditions, worldviews and customs of Nigerian users of the language. It is not because of the physical space they occupy, but because of the particular way they use English. These pragmatic features of the NE can only be understood when studied in relation to the Nigerian context. What this implies is that in the pragmatic use of English in Nigeria, the rules of English typical in native situations have been influenced and modified under pressure from the cultural practices of the Nigerian environment. With this understanding of pragmatic context, we analyze the use of NE in our sampled novels. This paper is divided into three parts: the first part deals with Nigerian English expressions; the second, Igboism/transliteration, and the third addresses code-switching as a discursive technique.

\section{Nigerian English Expressions}

Adichie's use of English in her artworks, like her contemporaries (other Nigerian novelists), can be described as Nigerian English, a variety of world Englishes. In their studies, scholars such as Udofot (2007), Eka (2002), Yeibo (2011), and others have authenticated the existence of a variety of English known as Nigerian English; it would be superfluous to argue here for or against its validity or existence. Adeniyi (2006) describes NE as "the variety of English spoken in Nigeria and used by Nigerians" (cited in Adedimiji, 2007, p. 4). Nigerian English plays an essential communicative function: to communicate across sociocultural boundaries and the multiplicities of languages that characterize the Nigerian multilingual society. Adichie uses this linguistic modality to communicate or instantiate the Nigerian-ness of her narrative discourse. Undeniably, her English is rooted in Nigerian experiences.

Since Nigerian speakers or users of English do not use the English language the same way that Britons, Americans or Australians do, we have identified some grammatical and culture-related English usages which reflect Nigerian expressions that are mere translations into English. Some of these expressions include:

1. '...Sucking fuel is a skill you need these days'. (Purple, 158)

2. '... This is not a good time for NEPA to take light...' (Purple, 165)

3. 'If some Bigman in Abuja has stolen the money, is the V.C. supposed to vomit money for Nsukka'? (Purple,139)

4. 'I thought Odenigbo's girl is a human being; he didn't say you were a water mermaid'. (Half, 283)

5. Master found a rain-holder on the wedding day. (Half, 245)
6. 'Has Onyeka touched you?' (Half, 121)

7. "Go and give that Ifemelu a talking-to..." (Americanah, 68)

8. He called Akunne a lurid illiterate, a moneymiss-road. (Americanah, 94)

9. 'Doesn't one of the commanding officers have a Hausa wife? She has put medicine in his food. (Half, 285)

The italicized parts of the expressions in the examples above highlight the cultural pragmatic patterns as well as the marked way English is used in Nigeria.

In 1, sucking fuel is the British English equivalent of siphoning fuel from one container to another. But Father Amadi deploys the expression "competently" because the context in which the expression is put to use insightfully depicts the accurate and functional reflexivity between meaning and context. It paints a time of fuel scarcity, a recurring dilemma in Nigeria. The expression implies that at such a time, one must learn the tricks of getting as much fuel as possible at a particular time, for no one can tell when one will find fuel to buy. It can then be said that it is the economic situation that informs the utterance, and in turn, the utterance resonates with the context of fuel scarcity.

The foregoing discussion suggests that one can hardly undermine the role of NE in giving expressive force to Nigeria's sociocultural reality. In 2, take light is pragmatically compelling as it is utilized to depict the incessant power outages that characterize power supply in Nigeria. To take light therefore describes the indiscriminate manner with which electricity is regulated or supplied in Nigeria. The verb take, therefore, is a Nigerian way of describing the outrageousness of the National Electric Power Authority (NEPA), officials, an entity that used to be the government's sole electric power generating and distributing agency. Aboh (2009, p. 94) writes that for many Nigerians, "NEPA means 'Never Expect Power Always'. This is informed by the fact that the agency is noted for its epileptic power supply". In the context of Purple, Amaka laments, "This is not a good time for NEPA to take light. I wanted to watch something on TV" (165). To "take light" acutely articulates Amaka's disdain with the way NEPA forcefully interrupts one's relaxation. It is perhaps important to say that different Nigerian languages have similar ways of describing the above act. NEPA ebo ikan, for example, is an Ibibio expression for NEPA has taken light: ebo means take/ taken and ikan means light.

Similarly in 3, there is the use of the Nigerian lexical unit Bigman. It is a Nigerian word for either a rich or a powerful man. It can also be used to describe some influential personality who either heads a unit or an establishment of government or one who is in private 
business and has made plenty of money. Invariably, bigman does not describe the size of a man, but the influence the man exerts. It depicts semantic shift/ extension that characterizes NE, which can be argued, distinguishes Nigerian English from other varieties of world Englishes. Bigman can also have a pejorative meaning, which is precisely the context in which it is used in Purple. It succinctly describes a corrupt government official who coverts the fund that was meant for the University of Nigeria, Nuskka. Obiora makes the case that it is impossible for the V.C. to vomit the money since he was not the person who stole it in the first instance. Although vomit is an English word, it has been contextually "Nigerianized" to aptly make a case for the V.C. The pragmatic intention attached to the use of the word is that the strike should be called off because it is absolutely difficult for one to regurgitate the contents of what one did not eat. Also embedded in Obiora's use of the Nigerian term is the fact that there exists a corrupt practice in Nigeria where "bigmen" steal public funds.

Example 4 is a communicative instance of reduplication that Nigerians utilize to stress a point. A superficial reading might interpret the expression as tautological since mermaids obviously live in water. However, the social context of use comes in quite handy here to illustrate how the expression, as used by Okeoma, signals Olanna's beauty. This is quite telling because in Nigeria, many believe that mermaids are especially beautiful; if there is any expression that fittingly captures Olanna's beauty, as far as Okeoma is concerned, it is a mermaid. So, she is as beautiful as a water mermaid.

The linguistic act of innovatively using language to capture events in their actual form informs the expression in number 5. A rain-holder refers to someone who has the capacity to control rain. This usage typifies the spiritual belief of some Nigerians that some people have spiritual powers, and they can use the powers to do many things. Perhaps the symbiotic intersection between language and culture is captured in this instance of language use. A rain-holder thus describes a person who wields spiritual power to either cause or stop rain from falling. This spiritual essence is exemplified when the rain-holder deters the rains from coming down during Odenigbo and Olanna's wedding.

Closely related to the above example is the use of touched you in number 6 . The silence that dominates the sacredness of sex and sex-related topics is carefully handled. Touched you euphemistically replaces direct references such as "made love to you or had sex with you" (Onukaogu \& Onyerionwu, 2010, p. 299). In Half, Ugwu, operating within the cultural semantics of his people, deploys touched you to find out if Onyeka, his sister's husband-to-be, has had sexual knowledge of her. Since it is culturally abominable to directly mention sexual acts and organs, Ugwu pragmatically uses touch you to mean "have sex". Interestingly, Anulika understands her brother because both of them share the same sociocultural background.

In the next example, there is the use of a talking-to. Unhappy with Ifemelu's behaviour of insubordination, her mother complains to Aunty Uju. She tells her to Go and give that Ifemelu a talking-to (68). A talking-to is to reprimand or to scold someone for misbehaving. In fact, the entire clause describes a Nigerian way of asking someone to urgently do something because of the fragility of the thing. Significantly, the expression captures the communal life of the Nigerian people where an elderly person can reprimand a younger one, even adults. Aunty Uju is Ifemelu's aunty, and because of familial bonds, Aunty Uju has the moral obligation to call her niece to order whenever she or any member of the family steps out of moral boundaries.

Example 8, Money-miss-road, also taken from Americanah, describes a wealthy man who does not know what to do with money or who is not worthy to be as rich as he is. And because such people have money when, perhaps, they least expected it, they behave in annoying ways. For example, Ifemelu's father is unhappy with the way Akunne treated him when he approached him for a loan. Ifemelu's father calls his illiterate cousin a money-miss-road. Perhaps many in Nigeria hold the view that the educated should have more money than the uneducated. This view plays itself out in the context of the novel; Akunne is rich but illiterate, so he is a money-miss-road.

In example 9, to put medicine in his food is to poison someone's food. This is the exact meaning of the Nigerian expression. But then, there are different kinds of medicines that can be put in someone's food; for example, love potion, as it turns out in the novel. It appears that many are of the view that when a man does everything a woman tells him, the woman has put a love potion in his food. Contextually, it is said that an Igbo leader does not support the Biafrian cause because he is married to a Hausa woman who has put medicine in his food. Therefore, the medicine has made him blind to his people's (Igbo) suffering.

The examples discussed here are non-standard English expressions that articulate Nigerian ideas in English words. Hence, even when the utterances are written with English words, they are heavily coded by the sociocultural life of Nigerians. It is this pragmatic use of English that distinguishes NE from other World Englishes. The fact is that these expressions have taken shape within Nigerian cultural ethos. Having examined the pragmaticism of Nigerian English expressions, we turn our attention now to another layer of NE expression known as Igboism. 


\section{Results and Discussion}

\section{Transliteration Equivalent: Igboism}

Adichie's experimentation with language is not only an articulation of her Nigerian-ness, but also her Igboness. One prominent feature that has greatly influenced the Nigerian creative writer is his/her "dual cultural heritage and orientation" (Onukaogu \& Onyerionwu, 2010, p. 265). This cultural heritage manifests itself in the writer's pragmatic utilization of the resources of language and construction of ideas. Because of such a bi-cultural identity, it is always the case that the Nigerian writer's use of language is an expression of indigenous thoughts in English words. When Adichie writes in "English", her Igbo cultural reality finds expression in her use of English, such that her sources of creativity are entirely Igbo; this is what Igboanusi (2001) describes as "Igboism". Igboism is, therefore, a feature of translation/transliteration.

Some Igboisms that portray Adichie as a bilingual writer are presented below:

10. ...little something for the children. (Purple, 68) (Igbo: Ihie n'takiri n'ke umu aka)

11. ... I ate money... (Purple, 97)

(Igbo: E'rigom ego)

12. ... balances Aunty Ifeoma's family on his head... (Purple, 29)

(Igbo: E'dokwasiri ezi na ulo anti ifeoma n'isi ya)

13. 'her chest is on fire'. (Half, 114)

(Igbo: Obi ya n'ere oku)

14. ...the bottom of his Pyjamas. (Purple, 29)

(Igbo: O'tula akwa o ji ehie ura)

Even a cursory glance at 10-14 reveals that the words are English but the ideas deeply communicate the Igboness of the novelist. In the preceding segment, we saw how Adichie writes in Igbo-like English; this section examines her effort to "Igbonize" the English language.

In example 10, Papa says "I want to give you a little something for the children". A "little something" is a polite way of saying one has a gift for someone. Even Mama uses the expression to tell the Reverend Sisters that she has a "little something" for them. The "little something" is "moin-moin" (pudding made from beans) she offered them. Beyond the linguistic coding of ideas, the expression defines humility and politeness. It is a polite Igbo way of giving something to others, such that the receiver does not feel belittled by the giver's magnanimous act.

Similarly, in example 11, the Priest says, "you people think I ate the money for the zinc, Okwia?" To "eat money" means to misappropriate, to siphon or to use money for personal interest. Ordinarily, one does not eat but spend money. It is a subtle way of denying that he did not covert the money meant to buy zinc for the church building. This is an instance of direct transliteration that marks the use of language in Adichie's novelistic discourse. Her linguistic inventiveness attests to the sociolinguistic truism that the English language can no longer claim any "linguistic purity"; it must compromise itself as it continues to spread all over the globe. We can say that Adichie uses a variety of Nigerian English known as Engli-Igbo. She herself, in an interview conducted by Azodo recounts:

I come from a generation of Nigerians who constantly negotiate two languages and sometimes three; if you include pidgin. For the Igbo in particular, ours is the Engli-Igbo generation and so to somehow claim that Igbo alone can capture our experiences is to limit it. (2008, p. 2)

One outstanding feature in the above comment is the fact that there are varieties of Nigerian English: just as there is Engli-Igbo for the Igbo writer, there is Engli-Yoruba for the Yoruba writer, Engli-Hausa for the Hausa writer, Engli-Ibibio for the Ibibio writer and so on. A critic of Nigerian literature can, thus, interpret the Igboness of Adichie's writings as a discourse strategy that enables her to give preeminence to her Igbo culture since she carefully intersperses her writings with Igbo cultural ideals.

In 12 , we see the conveyance of the Igbo thought system in the expression ...Papa balances Aunty Ifeoma's family on his head. The utterance simply means that Papa takes care of or is especially concerned about Aunty Ifeoma's welfare. When, for example, Aunty Ifeoma's university embarked on a strike action and lecturers were not paid salaries for months, Papa, Eugene, ensured that Aunty Ifeoma's family lacked nothing. And whenever Aunty Ifeoma asks for help from her brother, he endeavors to meet her need. In this case, the expression that aptly captures Papa's magnanimity is balances Aunty Ifeoma's family on his head.

It is this translational pattern that is seen

in 13 where Ugwu tells Odenigbo that:

'Sah, her chest is on fire'.

'Chest on fire?' Master snorted. (114)

Ugwu tells Odenigbo that his mother's "chest is on fire". And Odenigbo wonders how a person's chest could be on fire. This makes Odenigbo hurry to the village to see Ugwu's mother. For one's chest to be on fire is to have a chesty cough, that is, having phlegm in the lungs. Significantly, Ugwu's use of the translated expression adequately describes the nature of the cough - a burning feeling in the chest region when one coughs. This suggests that some NE expressions are transliterated indigenous language forms.

To wear the bottom of pyjamas, as indicated in 14, 
is to wear one's pyjamas inside out. Kambili uses the expression, a transliterated Igbo form, to depict the filial bond that exists between her and Jaja.

Based on our analysis, these Igboisms are effective ways of establishing Igbo cultural values in Adichie's creative enterprise since these Igboisms have cultural significations which help to create a connection between Adichie's creative mind and her origin. Needless to say, literature in the African context, as a recreation of human experience and language, is at the epicentre of such a recreation. No doubt, Adichie is able to recreate her Igbo ideology and identity through her careful use of Igboism.

\section{Code-Switching (CS)}

The third narrative device that Adichie deploys to "Nigerianize" her English is code-switching (CS). Gumperz defines CS as "the juxtaposition within the same speech exchange of passages of speech belonging to two different grammatical systems or subsystems" (1982, p. 59). In code-switched discourse, the items in question form part of the same speech act. They are tied together prosodically as well as by semantic and syntactic relations equivalent to those that join passages in a single speech act (Romaine, 1989, p. 111). Singh reserves the term "code-mixing" for intrasentential switching and uses "code-switching" for any diglossic situation where only one code is employed at a time, or cases where the code alternation refers to structurally identifiable stages or episodes of a speech event (1985, p. 34). In this segment, we use code-switching and code-mixing interchangeably. Our reason is that there is no clear-cut discursive distinction between the two sociolinguistic notions.

Let us examine some code-switched instances in Adichie's narrative enterprise as a way of nativizing English.

15. Aku n'efe, aku is flying. (Purple, 223)

16. 'I fukwa, people are leaving the country. Phillipa left two months ago ... (Purple, 84).

17. '... I preferred the stick to her slaps, though, because her hand is made of metal, ezi okwu'. (Purple, 250)

18. 'Tell them it is not yet your time! Gwa ha kita!' (Half, 117)

19. 'Ah! Sister! Aru Amaka gi! You look well!' (Half, 56)

20. 'Our eyes have seen plenty, anyi afunyugo'. (Half, 179)

21. 'Do not lie, Olanna Ozobia, Isikwana asi'. (Half, 236)

22. '...Amam atu inu, I even know proverbs...' (Americanah, 78)

23. 'Ife esika Kita, the recession is biting everybody'. (Americanah, 513)
24. 'Thirty five is too much, o rika, biko'. (Americanah, 288)

Adichie's code-switching strategy functions as distancing device as well as marks familiarity among discourse participants.

In 15 , a child from the neighboring flat screams, $A k u$ n'efe, $a k u$ is flying: he does so to alert other children in the compound to engage in the chase for $a k u$. Aku is an Igbo expression for an edible termite. The novelist uses two code forms: aku (Igbo) and English (is flying). We can therefore have "Termite is flying". This means that Adichie would have simply used the English code. Her preference to mix codes or switch codes enables her to "nativise" her English. Thus, we have two languages that are deployed to capture a reality. She does this to familiarise her readers with a delicacy of the Igbo. More to this is the fact that the use of the term shows class difference - while the boy calls it $a k u$, Aunty Ifeoma's children, whose mother is a lecturer, use the English name, termite. This is eminently the underlying pragmatic motivation!

The need to press home a point is the impetus for the code-switching device in 16. The use of ifukwayou see - functions as an argumentative anchor, as it is used to draw listener's attention to the plight of the striking lecturers who have not been paid for two months. Also, the code-switched element aptly depicts the brain drain situation in Nigeria, a situation where many Nigerian academics had to leave Nigeria for Europe and America owing to the inability of the Federal Government to improve staff welfare.

Adichie presents the use of ezi okwu - true - as emphasizer in 17. Ezi okwu, according to Onukaogu \& Onyerionwu (2010, p. 274), "serves as a conversational motivator for the interlocutor to reiterate an already given gist, expand the scope of the information or reveal different but related information". This agrees with our earlier view that the use of language in the Nigerian novel has some pragmatic alignments. Amaka tells Kambili that she prefers the sticks on her palms to her mother's slaps. When she brings in the Igbo term ezi okwu - she does so to strengthen her argument. So doing, the subtext to her message is that her mother does not spare them whenever they go wrong, and she can use her hands when a stick is not nearby.

In 18, the dibia encourages Ugwu's mother to ask "evil spirits" to let her be. The Igbo expression performs a supporting role even when it expresses the urgency as well as need for Ugwu's mother to verbally "attack the evil spirits" behind her illness. Although the Igbo form is the English equivalent of Tell them now!, it is functionally powerful as it carries the Igbo cultural belief that evil spirits are behind people's illness or misfortune. It also means that if one is able to confront evil spirits, they will let the person be. But the main idea, as Adichie switches code, is to enable 
her to present the verbal confrontation the exact way it is captured in Igbo.

The switch between codes to give expressive force to Adichie's "English" is presented in 19. Arize switches from English to Igbo and back to English. Such switches are informed by the social status of the discourse participants. Arize knows that Olanna is educated and she has to make her conversation relevant by switching from one code to another. In so doing, she is able not to maintain the familiar tie between herself and Olanna, but also to construct a social identity for herself. Aru Amaka gi means one looks good/beautiful. If the translated form is provided, why does the novelist bring in the Igbo code? This, perhaps, is deliberate - willingness to demonstrate her bi-cultural linguistic reality.

The communicative need to graphically present the emotional and mental imbalance the Igbo faced in the north at the outset of the Nigerian civil war is the reason for the use of anyi afunyugo in example $20,-$ means "we have been through a lot of hardship". This metapragmatic use of language becomes quite compelling as it details how context gives force to as well as informs the linguistic choices speakers make in conversational situations. Obiozor tells Odenigbo that "their eyes have seen plenty". This expression cinematically defines the pre-war horror the Igbo came under. The expression can also be said to be euphemistic (sentential) as it conceals the pogrom the speaker and his tribe faced in the north. But then, it describes the Nigerian novelist's effort to "bend" the English language, so as to capture his/her indigenous speech forms in his/her artwork.

In number 21, the speaker switches codes to enable her to express doubt. The statements are uttered in English, but the translated Igbo forms are deployed to heighten the persuasive intent of the discussants. This translational device is to provide an Igbo equivalent of the English form. Mama Dosie, for example, persuades Olanna to tell the truth since she does not believe Olanna's account of the pogrom in the north. Contextually, isikwana asi implores Olanna to tell them the exact thing she saw when the pogrom started in the north.

In number 22, Obinze and his friend challenge each other on their ability to speak Igbo. When his friend doubts his ability to speak Igbo, Obinze remarks Ama m atu inu. I even know proverbs. The change of code from English to Igbo is a pragmatic move, an act intended by Obinze to convince his friend that he does not only speak, but also knows how to punctuate his speech with Igbo proverbs. The Igbo code carries the sub-act of emphasis, as it emphasizes the fact that Obinze can speak Igbo as well as knows how to use Igbo proverbs.

Edusco, Obinze's friend, switches to Igbo in 23 to make it possible for him to draw attention to the prevalent economic situation in Nigeria. Obinze, on returning to Nigeria from America, wants to buy a piece of land. The price Edusco asks him to pay is too high. In a bid to haggle down the price, Obinze tells Edusco that the recession has made things difficult and people do not really have money. Edusco switches to Igbo in order to clarify that no one is exempt from the hardship brought about by the economic recession.

The need to emphasize what a speaker says is the motivation for the code-switching in example 24 . Obinze needs an illegal passport that will prolong his stay in America and Iloba takes him to Vincent Obi, an Igbo man who does the illegal business. They (Obinze and Iloba) had thought that meeting an Igbo person will make it easier for them. Unfortunately, Vincent is cut out for business and does not give ethnic origin consideration. Iloba's code-switching technique is to remind Vincent of familial bond, to see the need to help a brother. In this case, as have other examples discussed in this segment, code-switching is portrayed as a conversational strategy discourse participants deploy to achieve set communicative goals.

\section{Conclusion}

By examining the pragmatic use of English in Nigeria as depicted by Adichie in her novels, this paper uncovers how some of the expressions taken to be English may be difficult for native English speakers to understand because they are written with English words but convey Igbo/Nigerian cultural thoughts. It follows that Adichie's linguistic inventiveness is a product of her Igbo sociocultural background interfacing with the larger Nigerian linguistic axiom; in this way she creates a variety of English that enables her to communicate her own cultural realities to other parts of the world. An understanding of Adichie's novels thus requires a focus on the constraining contextual factors that shape her particular use of language.

\section{References}

Aboh, R. (2009). Socio-linguistic innovations in modern poetry. The Journal of New Poetry, 6, 87-108. Aboh, R., \& Uduk, H. (2015). Linguistic variation in the Nigerian novel: A socio-pragmatic investigation. Wilberforce Island Review, A Journal of the Faculty of Arts, 13, 165-186.

Adedimiji, M. (2012). The linguistic features of Nigerian English and their implications for 21st century English pedagogy. Unpublished paper presented at 
the 24th Annual Conference of the Nigeria English Study Association (NESA). University of Uyo, Uyo, Nigeria.

Adichie, C. (2004). Purple hibiscus. Lagos, Nigeria: Farafina.

Adichie, C. (2006). Half of a yellow sun. Lagos, Nigeria: Farafina.

Adichie, C. (2008, April 24). Interview by A. Azodo. In Creative writing and literary activism. Western Illinois University, Macomb, IL. Retrieved from http://www.iun.edu/ minaua/interviews/ interview_chimamanda_ngozi_adichie.pdf

Adichie, C. (2013). Americanh. Lagos, Nigeria: Farafina.

Akujobi, R. (2014). Elements of Nigerian English in Nigerian literature: An appraisal of Kaine Agary's Yellow yellow and Ben Okri's Converging city. Ona: Journal of English Language and Literature, 2, 105113.

Anyokwu, C. (2011). Igbo rhetoric and the new Nigerian novel: Chimamanda Ngozi Adichie's Purple hibiscus. The African Symposium, 11(1), 80-90.

Eka, D. (2000). Issues in Nigerian English usage. Uyo, Nigeria: Scholars Press.

Gumperz, J. J. (1982). Discourse strategies. Cambridge, UK: Cambridge University Press.

Igboanusi, H. (2001). The Igbo tradition in the Nigerian novel. African Study Monographs, 22, 53-72.

Odebunmi, A. (2006). Meaning in English: An introduction. Ogbomoso, Nigeria: Critical Sphere.

Odebunmi, A. (2015). Pragmatics. In I. Kamalu \& I. Tamunobelema (Eds.), Issues in the study of language and literature: Theory \& practice (pp. 196221). Ibadan, Nigeria: Kraft Books.
Ogwude,S.(2011).History and ideology in Chimamanda Adichie's fiction. Tydskrif Vir Letterkunde, 48(1), 110-123.

Okoh, N. (2012, November 22). Of synergies: Linking literature, language and English in Nigeria. Inaugural lecture series, 97. University of Port Harcourt, Port Harcourt, Nigeria. Retrieved from http://www.uniport.edu.ng/files/Inaugural\%20 Lectures/97th\%20Inaugural\%20Lecture_2012\%20 by\%20Prof\%20Nkem\%200koh.pdf

Olusola, L. M., \& Alabi, L. F. (2013). Language and ideology in Chimamanda Adichie's Purple hibiscus. Journal of Humanities and Social Science, 13(1), 8-16.

Onukaogu,A.A., \& Onyerionwu,E.(2010). Chimamanda Ngozi Adichie: The aesthetics of commitment and narrative. Ibadan, Nigeria: Kraft Books.

Romaine, S. (1989). Bilingualism. Oxford, UK: Blackwell.

Singh, R. (1985). Grammatical constraints on codeswitching: Evidence from Hindi-English. Canadian Journal of Linguistics, 30, 33-45.

Udofot, I. (2007). English and the Nigerian situation Trends and imperatives. Unpublished inaugural lecture delivered in the University of Uyo, Uyo, Nigeria.

Yeibo, E. (2011). Nativization of English in African literary texts: A lexico-semantic study of transliteration in Gabriel Okara's The voice. International Journal of Humanities and Social Sciences, 1, 9-13.

Yeibo, E., \& Akerele, C. (2014). Phonological foregrounding in Chimamanda Adichie's Purple hibiscus. International Journal of Language and Linguistics, 1(2), 61-71. 